\title{
PENGEMBANGAN MEDIA STEKPAN UNTUK KOGNITIF ANAK USIA 4-5 TAHUN
}

\author{
Sri Widayati ${ }^{1}$; Nurhenti Dorlina Simatupang ${ }^{1}$; Wulan Patria Saroinsong ${ }^{2}$; Aryn Rusdiyanti ${ }^{3}$ \\ PG-PAUD, Fakultas Ilmu Pendidikan, Universitas Negeri Surabaya, \\ Jl. Lidah Wetan, Surabaya, 60213 \\ Penulis untuk Korespondensi/ E-mail: sriwidayati@unesa.ac.id
}

\begin{abstract}
Abstrak - Penelitian ini dilakukan oleh peneliti untuk mengetahui pengembangan produk, desain prototype dan keefektifan penggunaan video tutorial penggunaan media STEKPAN guna membantu orang tua anak usia 4-5 tahun untuk meningkatkan kemampuan mengenal konsep bilangan 1-10 pada anak usia 4-5 tahun. Jenis penelitian ini merupakan jenis penelitian R\&D (Reaserch and Development) dengan menggunakan model ADDIE, yaitu Analysis, Design, Development, Implementation, Evaluation. Penelitian ini hanya dilakukan sampai pada tahap Development atau pengembangan. Validasi produk dilakukan melalui google form dengan hasil bahwa media STEKPAN layak digunakan dan diproduksi. Pengumpulan data pada penelitian ini menggunakan kuisioner yang ditujukan kepada 50 responden yaitu orang tua anak usia 4-5 tahun melalui Google Form. Hasil dari penelitian ini berupa video tutorial penggunaan media STEKPAN yaitu Stik Es Krim Papan. Hasil feedback orang tua menyatakan bahwa media STEKPAN layak dan efektif digunakan untuk meningkatkan kemampuan mengenal konsep bilangan 1-10 untuk anak usia 4-5 tahun. Implikasi penelitian ini adalah pada aspek kebermanfaatan video tutorial penggunaan media STEKPAN yang positif, dimana orang tua memiliki pengetahuan tambahan bagaimana cara untuk menstimulus perkembangan kognitif anak melalui media STEKPAN.
\end{abstract}

Kata Kunci: Media Pembelajaran, Stik Es Krim , Kognitif , Lambang Bilangan, Anak Usia 4-5 Tahun.

Abstract - This research was conducted by researchers to learn about product development, prototype design and effectiveness of using video tutorials of STEKPAN media to help parents of children aged 4-5 years to improve the ability to recognize the concept of numbers 1-10 in children aged 4-5 years. This type of research is a type of $R \& D$ (Reaserch and Development) research, researchers using ADDIE model, that is Analysis, Design, Development, Implementation, Evaluation. This research is only done up to the stage of Development. Product validation is done through google form with the result that STEKPAN media is worth using and producing. Data collection in this research used questionnaires addressed to 50 respondents, that is parents of children aged 4-5 through Google Form. The result of this research is a video tutorial on the use of STEKPAN media, that is Ice Cream Board Sticks. The results of parental feedback stated that STEKPAN media is feasible and effectively used to improve the ability to recognize the concept of numbers 1-10 for children aged 4-5 years. The implication of this research is on the usefulness aspect of positive STEKPAN media use video tutorials, where parents are more now how to stimulate a child's cognitive development through STEKPAN media.

Keywords: Learning Media, Ice Cream Sticks, Cognitive, Numbers Symbols, Children Aged 4-5 Years 


\section{PENDAHULUAN}

$\mathrm{P}$ endidikan Anak Usia Dini memiliki tujuan untuk mengembangkan beberapa aspek, antara lain aspek kognitif, bahasa, fisik motorik, sosial, nilai agama dan moral, seni, bahasa supaya anak memiliki kesiapan dalam memasuki pendidikan lebih lanjut. Perkembangan aspek kognitif merupakan salah satu aspek perkembangan yang penting untuk anak usia dini. Kognitif merupakan bagian intelek yang merujuk pada penerimaan, penafsiran, pemikiran, pengingatan, pengkhayalan, pengambilan keputusan dan penalaran (Umayah \& Khotimah, 2015). Kognitif adalah bagaimana anak beradaptasi dan menginterpretasikan objek dan kejadian-kejadian di sekitarnya Parwati, dkk. (2013). Berdasarkan penjelasan-penjelasan di atas maka dapat ditarik kesimpulan bahwa perkembangan kognitif merupakan proses perkembangan pada otak setiap individu yang memiliki kemampuan berfikir menganalisa ataupun memecahkan masalah dengan menggunakan daya ingat.

Aspek perkembangan kognitif memiliki banyak cabang, diantaranya adalah kognitif tentang matematika. Matematika merupakan salah satu aspek yang dapat menstimulus perkembangan kognitif anak. Matematika memiliki peranan penting dalam kehidupan sehari-hari seperti menghitung benda di sekitarnya, terkait jual beli, melihat waktu (jam), dan sebagainya. Oleh sebab itu, matematika perlu diajarkan sejak dini pada diri anak. Terkait dengan hal tersebut bahwa ilmu yang dipelajari dalam matematika ialah bilangan, bangunan, dan konsep-konsep yang berkenan dengan kebenarannya secara logika, menggunakan simbol-simbol kebenarannya secara logika, menggunakan simbolsimbol yang umum serta aplikasi dalam bidang lainnya Jannah (2011). Menurut Montolalu, matematika adalah sesuatu sistem abstrak untuk pengalaman dalam mengorganisasikan serta mengurutkan. Anak usia dini berpikir awal secara konkret, konsep-konsep atau urutan tidak akan berarti apa-apa bagi mereka kecuali mereka memiliki sesuatu benda yang konkret untuk bisa dihitung dan diurutkan Fauziddin (2015).

Menurut Susanto (dalam Fedriyenti, 2020) pembelajaran matematika pada anak usia dini hendaknya diberikan melalui bermain. Belajar melalui bermain merupakan suatu teknik pengajaran dan pembelajaran yang berkesan kepada anak usia dini. Selain dilakukan dengan bermain, pembelajaran yang menyenangkan juga memerlukan media yang menarik dan tepat bagi anak usia dini.
Media merupakan suatu alat atau sarana sebagai perantara untuk menyampaikan bahan pelajaran dari guru kepada anak didik Rasyid dan Rohani (2018).

Sadiman (dalam Azhari, 2018) mengungkapkan media pembelajaran adalah segala sesuatu yang digunakan untuk menyalurkan pesan dari pengirim ke penerima sehingga dapat merangsang pikiran, perasaan, perhatian dan minat serta perhatian anak sehingga proses belajar terjadi. Hal ini juga diperkuat oleh Miaso (dalam Nursalim, 2019). media adalah segala sesuatu yang digunakan untuk menyalurkan pesan yang dapat merangsang pikiran, perasaan, perhatian dan kemauanan anak untuk belajar. Pada era sekarang dalam menggunakan media pembelajaran telah banyak dilakukan, teruatama pembelajaran dalam mengenal konsep bilangan. Menggunakan media pembelajaran pada anak usia dini akan membuat anak lebih tertarik untuk belajar dan memberi kesan yang menyenangkan.

Menurut Yeni (2015), Matematika sering dijadikan sesuatu hal yang menakutkan atau momok bagi anak karena sulit dipahami dan bersifat abstrak sehingga membuat anak malas untuk mempelajarinya. Jika melihat bagaimana terkaitnya matematika dalam kehidupan sehari-hari, maka akan dapat diprediksi bagaimana sulitnya anak dalam kehidupan sosialnya jika tidak dapat memahami matematika dengan baik.

Terkait permasalahan Matematika, peneliti melakukan observasi ke TK Bina Tunas Bangsa Lidah Wetan Surabaya pada tanggal 10 Februari 2020. Peneliti menemukan 75\% (15 anak) dari 20 anak kelompok A mampu berhitung dengan urut secara lisan bilangan 1-10, namun anak belum mampu memahami simbol dari bilangan itu sendiri. Sisanya 25\% (5 anak) sudah mampu berhitung dengan urut secara lisan bilangan 1-10 dan memahami simbol dari bilangan itu sendiri.

Pada penelitian terdahulu oleh Suhariyanik (2016) yang berjudul "Mengembangkan Kemampuan Berhitung dalam Mengenal Bilangan 1-10 Menggunakan Media Stik Es Krim Pada Anak Kelompok A TK Kusuma Mulia II Kecamatan Tarokan Kabupaten Kediri" merupakan penelitian yang bertujuan untuk meninhkatkan kemampuan berhitung bilangan 1-10 menggunakan media stik es krim. Pada penelitian Suhariyanik membuktikan bahwa dengan menggunakan stik es krim dalam kegiatan pembelajaran berhitung pada mampu meningkatkan kemampuan pada anak.

Begitu pula pada penelitian yang dilakukan oleh 
Nurhayati \& Kharizmi (2020) berjudul "Penggunaan Media Stik Es Krim Untuk Meningkatkan Kemampuan Mengenal Konsep Bilangan Pada Anak Usia Dini Di TKS Tiga Serangkai Geulumpang Sulu Timur" yang merupakan penilitian untuk meningkatkan kemampuan mengenal konsep bilangan pada anak usia dini menggunakan stik es krim. Peneliti menemukan permasalahan pada metode pembelajaran yang digunakan oleh para guru disana yang masih menggunakan LKA atau lembar kerja anak sehingga motivasi anak untuk belajar kurang. Sama dengan halnya pada penelitian ini, di mana peneliti telah melakukan observasi penelitian pada kelompok A di TK Bina Tunas Bangsa Surabaya yang mana kegiatan pembelajaran yang diberikan pada anak masih menggunakan LKA yang monoton dan kurang memanfaatkan media atau permainan yang memotivasi anak untuk mempelajari konsep bilangan.

Maka dari itu peneliti ingin mengembangkan sebuah media pembelajaran yang berbahan dasar stik es krim dan telah dimodifikasi. Pengembangan media yang dilakukan peneliti bernama media pembelajaran STEKPAN atau nama panjangnya stik es krim dalam papan ini memiliki beberapa tingkatan dalam permainan. Adapun bagian yang terdapat pada media STEKPAN ini adalah papan berkantong, stik es krim, kartu angka, dan juga dadu angka. Peneliti memilih untuk mengembangkan stik es krim menjadi media STEKPAN karena media ini lebih praktis digunakan oleh anak, menggunakan bahan yang ringan dan tidak berbahaya bagi anak, media permainan yang menyenangkan, tepat dan efektif untuk dimainkan oleh anak usia 4-5 tahun. Sejalan dengan perkembangan kognitif seseorang, Lillard (2013) mengungkapkan perkembangan kognitif terjadi melalui tiga tahap yaitu tahap efektif, tahap ikonik, dan tahap simbolik. Tahap efektif terjadi pada usia 0-2 tahun, tahap ikonik terjadi pada usia 2-4 tahun, dan tahap simbolik terjadi pada usia 5-7 tahun. Selain itu Trisnawaty (2017) mengungkapkan bahwa perkembangan berpikir simbolic pada anak termasuk kemampuan mengenali, menyebutkan, mampu menggunakan bilangan, mengenali huruf dan mampu mempresentasikan banyak objek dan objek imajinasinya. Berdasarkan kedua pendapat diatas maka untuk menguatkan kemampuan berpikir simbolic pada anakdalam hal mampu mengenali simbol bilangan dan dapat menggunakannya maka dari itu, anak usia 4-5 tahun perlu menggunakan media. Salah satu media ini adalah media STEKPAN sebagai alat bantu untuk mengajarkan konsep bilangan 1-10 pada anak.

\section{METODE PENELITIAN}

Jenis penelitian ini merupakan jenis penelitian dan pengembangan (Research and development). Sugiyono Sulistyo (2019) menjelaskan penelitian dan pengembangan (R\&D) merupakan metode penelitian yang digunakan untuk menghasilkan rancangan produk tertentu, menguji efektivitas, validitas rancangan yang telah dibuat sehingga produk menjadi teruji dan dapat dimanfaatkan oleh umum. Menghasilkan produk tertentu digunakan untuk penelitian yang bersifat analisis kebutuhan dan dilakukan uji efektivitas supaya produk dapat digunakan oleh masyarakat. Menurut Sukmadinata $\mathrm{R} \& \mathrm{D}$ adalah langkah-langkah untuk mengembangkan dan menyempurnakan suatu produk yang telah ada, dan dapat dipertanggung jawabkan (Putra, 2018).

Penelitian ini menggunakan model ADDIE yang hanya dijalankan hingga tahap Development atau pengembangan. Pengembangan media dilakukan untuk memperoleh terobosan guna mengembangkan media STEKPAN agar media yang dikembangkan lebih praktis, efesien, dan bermanfaat bagi kemajuan dalam pendidikan anak usia dini. Penelitian ini bertujuan untuk mengetahui efektifitas penggunaan video tutorial penggunaan media STEKPAN pada orang tua anak usia 4-5 tahun untuk mengajarkan atau mengenalkan konsep bilangan 1-10 pada anak usia 4-5 tahun.

Desain Penelitian pengembangan ini menggunakan Desain Model ADDIE. Menurut Supart dan Susanti (2017), model ADDIE merupakan salah satu tahapan standar dalam proses pengembangan model media yang dimulai dengan analisis, desain, pengembangan sampai dihasilkannya sebuah prototipe model yang siap diimplementasikan untuk mendapatkan umpan balik melalui tahap evaluasi. Hal ini sejalan dengan pendapat Sofnidar \& Yuliana (2018) model penelitian ADDIE digambarkan sebagai berikut:

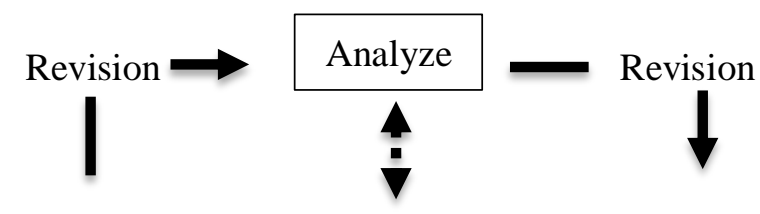




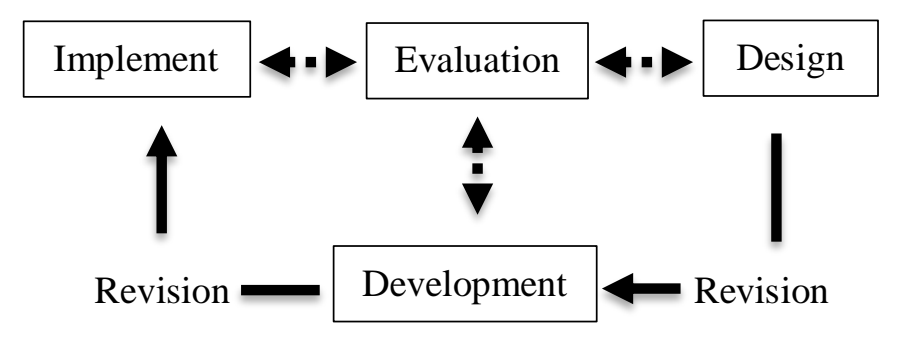

Gambar 1. Model ADDIE menurut Branch

(Sofnidar dan Yuliana, 2018)

Adapun penjelasan pada tiap tahap di atas sebagai berikut:

1. Tahap Analisis (analyze)

Pada tahap analisis, peneliti melakukan kegiatan observasi pada anak usia 4-5 tahun atau anak kelompok A. Peneliti menemukan permasalahan yang sedang terjadi yaitu anakanak mengalami kesulitan dalam memahami konsep bilangan 1-10.

2. Tahap Perancangan (design)

Setelah dilakukannya analisis pada perkembangan anak, tahap selanjutnya adalah melakukan perancangan produk. Produk yang dipilih oleh peneliti adalah media Stik Es Krim Papan (STEKPAN). Peneliti membuat konsep rancangan desaign media STEKPAN yang disesuaikan dengan konsep design yang disukai anak-anak.

3. Pengembangan (development)

Pengembangan disini dapat diartikan sebagai pengembangan desaign media menuju media secara utuh atau produk. Setelah menjadi produk maka akan dilakukan memvalidasi produk oleh ahli materi dan ahli media. Berikut prosedur pada tahap pengembangan:

a. Merealisasikan rancangan menjadi sebuah produk media STEKPAN untuk meningkatkan kemampuan mengenal konsep bilangan 1-10 pada anak usia 4-5 tahun.

b. Produk yang telah dikembangkan selanjutnya dilakukan validasi kepada validator ahli materi dan ahli media untuk mendapatkan saran terhadap kelayakan produk. Peneliti memilih dua dosen jurusan PG-PAUD Universitas Negeri Surabaya sebagai validator dalam penelitian ini.

c. Menghitung presentase hasil kelayakan media STEKPAN ditentukan menggunakan rumus melalui perhitungan berdasarkan pengukuran instrumen kelayakan.

4. Implementasi (implementation)

5. Evalusi (evaluation)

Populasi dalam penelitian yaitu orang tua anak usia 4-5 tahun di Kota Surabaya. Pada penelitian ini peneliti menggunakan sampel sebanyak 50 orang tua anak usai 4-5 tahun di Surabaya. Sampel penelitian ditentukan menggunakan teknik purposive sampling.

Tabel 1. Kriteria Persentase Kelayakan Produk

\begin{tabular}{|c|c|c|}
\hline Presentase & Kriteria & Keterangan \\
\hline $81 \%-100 \%$ & Baik Sekali & $\begin{array}{c}\text { Sangat } \\
\text { dibutuhkan/layak }\end{array}$ \\
\hline $61 \%-80 \%$ & Baik & Dibutuhkan/layak \\
\hline $41 \%-60 \%$ & Cukup baik & $\begin{array}{c}\text { Cukup } \\
\text { dibutuhkan/cukup } \\
\text { layak }\end{array}$ \\
\hline $21 \%-40 \%$ & Kurang Baik & $\begin{array}{c}\text { Kurang } \\
\text { dibutuhkan/kurang } \\
\text { layak }\end{array}$ \\
\hline $0 \%-20 \%$ & $\begin{array}{c}\text { Tidak Baik } \\
\text { Sekali }\end{array}$ & $\begin{array}{c}\text { Kurang } \\
\text { dibutuhkan/kurang } \\
\text { layak }\end{array}$ \\
\hline
\end{tabular}

Sumber: Rumus dan Data dalam Analisis Statistika (Akdon dan Riduwan, 2013)

Data hasil kuisioner didapat dari ahli materi dan Ahli Desain Pembelajaran AUD dihitung memakai rumus berikut (Sugiono, 2014):

$$
\mathbf{K}=\frac{T s e}{T s h} \times 100 \%
$$

Gambar 2. Rumus perhitungan data validasi produk

\section{Keterangan:}

K : Presentase Kelayakan buku panduan

Tse : Total skor empirik yang didapatkan

Tsh : Total skor angket maksimal yang diinginkan 
Selanjutnya, menghitung data kuisioner yang didapat dari hasil uji kelayakan media STEKPAN dari 50 orang tua anak usia 4-5 tahun, akan dihitung memakai rumus sebagai berikut (Sugiono, 2014):

$$
\mathbf{K}=\frac{T s e}{T s h} \times 100 \%
$$

Gambar 3. Rumus perhitungan data kuesioner

Keterangan:

K : Persentase Kelayakan dari buku panduan

Tse : Total skor empirik yang didapatkan

Tsh : Total skor angket maksimal yang diinginkan

Lalu analisis dilanjut dengan memakai rumus yang diadaptasi dari perhitungan validitas gabungan berikut (Sugiono, 2014):

$$
\mathrm{Kgab}=\frac{\sum k}{N} \mathrm{X} \ldots \%
$$

Gambar 4. Rumus perhitungan validitas gabungan

Keterangan :

Kgab : Kelayakan gabungan

$\sum k \quad$ :Total prsentase kelayakan buku panduan yang diperoleh

$\mathrm{N} \quad$ : Jumlah responden

\section{HASIL DAN PEMBAHASAN}

Pengembangan media STEKPAN ini selaras dengan tiap tahapan pada model pengembangan ADDIE. Mengenai implementasi 5 tahapan model pengembangan ADDIE yang dipakai dalam proses pengembangan dan penelitian ini akan dijelaskan sebagai berikut:

\section{Analisis (Analysis)}

Pada tahap analisis penellitian ini adalah menganalisis kebutuhan dasar anak beserta permasalahan apa yang dialami saat pelaksanaan belajar. Permasalahn yag dijumpai oleh penelit adalah kurangnya pemahaman anak usia 4-5 tahun mengenai konsep bilangan 1-10. Anak cenderung menghafal dari pada memahami. Setelah dilakukannya observasi oleh peneliti yang dilaksanakan pada tanggal 10 Februari 2020 di TK Tunas Bangsa Surabaya, peneliti melihat bahwa guru cenderung mengajarkan pada anak melalui Lembar Kerja Anak atau LKA. Guru kurang memaksimalkan media yang dimiliki untuk memberikan pembelajaran pada anak sehingga terasa monoton dan anak menjadi bosan. Belum ditambah lagi dengan Pekerjaan Rumah atau PR yang harus dikerjakan oleh anak dan yang juga berupa LKA.

Permasalahan yang ditemukan oleh peneliti mendorong peneliti untuk mengembangkan sebuah media pembelajaran inovatif yang bertujuan untuk membantu anak dalam meningkatkan kemampuan mengenal konsep bilangan 1-10 pada anak usia 4-5 tahun.

\section{Desain (Design)}

Setelah dilakukannya analisis pada perkembangan anak, tahap selanjutnya adalah melakukan perancangan produk. Produk yang dipilih oleh peneliti adalah media Stik Es Krim Papan (STEKPAN). Peneliti membuat konsep rancangan desaign media STEKPAN yang disesuaikan dengan konsep design yang disukai anak-anak. Desain produk menggunakan software coreldraw, lalu mempersiapkan bahan-bahan yang digunakan. Berikut hasil rancangan tiap bagian produk STEKPAN:

\section{a. Papan berkantong STEKPAN}

Papan ini terbuat dari impraboard yang dibentuk menyerupai segitiga sehingga dapat berdiri tegak dengan sendirinya. Terdiri dari dua bagian, yaitu papan dan wadah untuk stik es krim. Ukuran papan yang digunakan ialah 20x9x15 cm (panjang $\mathrm{x}$ lebar $\mathrm{x}$ tinggi). Wadah yang digunakan berukuran $8 \times 4 \mathrm{~cm}$. Wadah tersebut juga sama menggunakan bahan impraboard. Peneliti memilih menggunakan impraboard karena bahan ringan dan aman bagi anak.

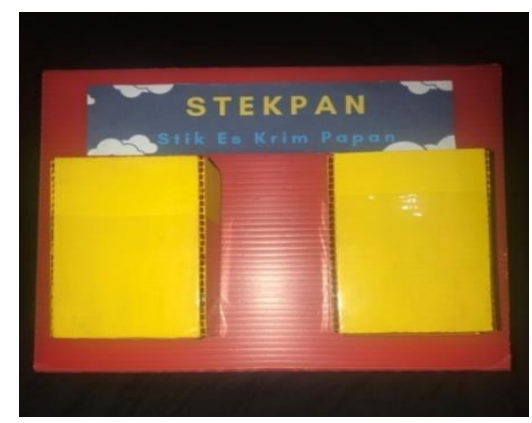

Gambar 5. Papan Berkantong STEKPAN 
b. Stik Es Krim

Stik es krim yang digunakan ialah stik es krim kayu berukuran $11,5 \mathrm{~cm}$ x $1 \mathrm{~cm}$

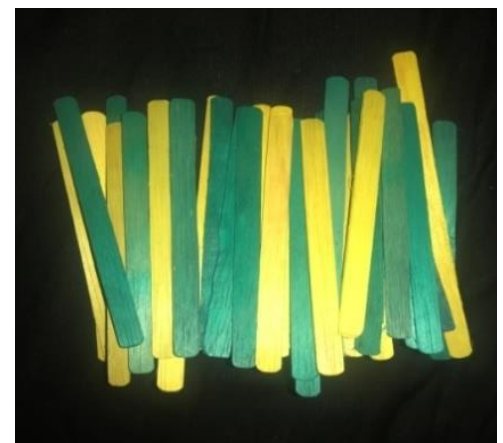

Gambar 6. Stik Es Krim

c. Dadu Angka

Dadu angka pada media STEKPAN ini terbuat dari kertas karton. Dipilihnya kertas karton karena memiliki ketebalan yang pas sehingga mudah dibentuk menjadi bentuk seperti dibawah sebanyak 10 sisi yang mana sisi itu pas dengan angka yang akan diajarkan pada anak usia 4-5 tahun yaitu angka 1-10.

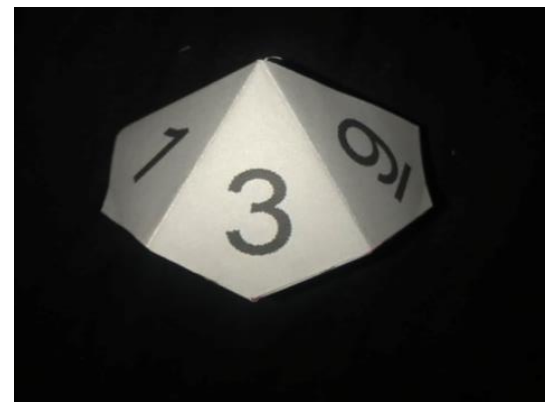

Gambar 7. Dadu Angka

d. Kartu Angka

Kartu angka dibuat menggunakan bahan kertas karton yang berukuran 9x6 cm yang selanjutnya ditempel dengan kertas hvs print dari desain kartu angka yang telah dibuat, baik bagian depan maupun belakang. Kartu angka ini sendiri juga memiliki tempat yang sama terbuat dari kertas karton dan ditempel dengan kertas hvs print sesuai dengan desain yang telah dibuat. Kartu angka berjumlah 10 sesuai dengan konsep bilangan yang akan diajarkan pada anak yaitu bilangan 1-10

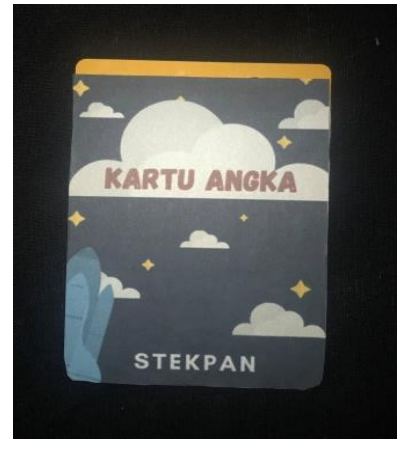

Gambar 8. Bagian Depan Kartu Angka

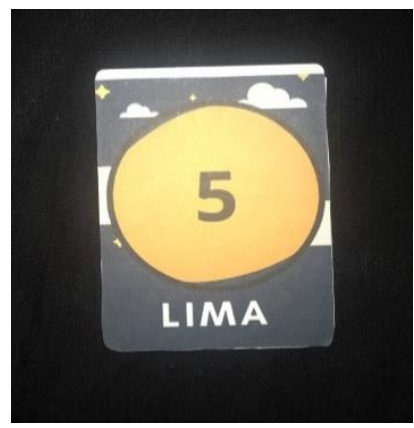

Gambar 9. Bagian Belakang Kartu Angka

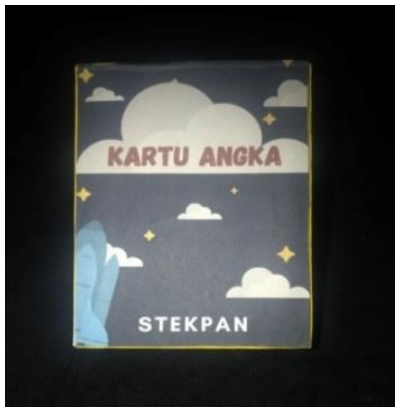

Gambar 10. Tempat Kartu Angka

3. Pengembangan (Developtment)

Pengembangan disini dapat diartikan sebagai pengembangan desaign media menuju media secara utuh atau produk. Produk yang telah dikembangkan selanjutnya dilakukan validasi kepada validator ahli materi dan ahli media untuk mendapatkan saran terhadap kelayakan produk.

Adapun hasil validasi media dan validasi materi pada media STEKPAN menurut ahli adalah produk STEKPAN memiliki materi yang tepat dan baik bagi anak usia 4-5 tahun sehingga dinyatakan bahwa media STEKPAN layak untuk diproduksi tanpa revisi. Adapun persentase yang didapatkan ialah sebanyak $89 \%$ menyatakan produk STEKPAN layak digunakan dan ahli media sebesar $90 \%$ juga menyatakan hal yang sama. 
Tabel 4. Hasil Persantese Validasi Ahli Materi dan Ahli Media

\begin{tabular}{|l|l|l|}
\hline Validasi & \multicolumn{1}{|c|}{$\begin{array}{c}\text { Hasil } \\
\text { Persentase }\end{array}$} & \multicolumn{1}{|c|}{ Keterangan } \\
\hline Ahli Materi & $89 \%$ & $\begin{array}{l}\text { Sangat Layak } \\
\text { Digunakan }\end{array}$ \\
\hline Ahli Media & $90 \%$ & $\begin{array}{l}\text { Sangat Layak } \\
\text { Digunakan }\end{array}$ \\
\hline
\end{tabular}

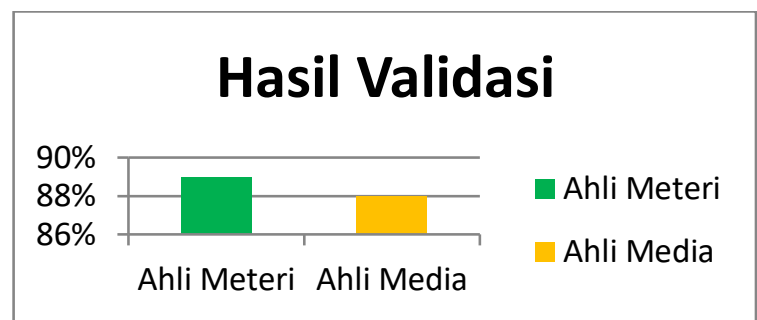

Gambar 13. Diagram Hasil Persantese Validasi Ahli Materi dan Ahli Media

Kesimpulan dari hasil validasi ahli media dan ahli materi adalah bahwa media STEKPAN sangat layak digunakan untuk anak usia 4-5 tahun untuk mengenalkan konsep bilangan 1-10 dan layak untuk diproduksi.

Pada penelitian ini peneliti menggunakan 50 sampel orang tua anak berusia 4-5 tahun di Surabaya. Selanjutnya setelah peneliti memvalidasi produk kepada ahli media maupun ahli materi, peneliti melakukan uji validatis terhadap poin pertanyaan persepsi orang tua yang berkaitan dengan media STEKPAN yang mengaju pada keseluruhan produk. Perhitungan Uji Validitas menggunakan SPSS 23 dengan taraf sig 0,05 , uji validitas feedback orang tua terhadap media STEKPAN dengan hasil $r$ di atas $(0,17)$ pada setiap poin pertanyaan maka dinyatakan valid karena $r$ tabel $>r$ hitung.

Untuk Uji Reliabilitas dalam penelitian ini peneliti menggunakan rumus Cronbach's Alpha yang dihasilkan pada kuisioner orang tua terhadap penggunaan media STEKPAN sebesar 0,683. Dimana dapat diartikan bahwa nilai koefisien untuk media STEKPAN di atas 0,6. Hasil uji reliabilitas kuisioner tersebut terbukti bahwa reliabel tinggi.

Media STEKPAN akan diuji kelayakan melalui kuisioner penilaian atau feedback yang diberikan kepada orang tua anak usia 4-5 tahun berjumlah 50 orang. Di dalam quisioner tersebut para orangtua diberikan video tutorial penggunaan media stekpan dan selanjutnya setelah menonton video tersebut orang tua baru menjawab angket yang ada dalam google form. Data dari angket selanjutnya akan dilakukan uji statistik deskriptif mengenai kelayakan media STEKPAN.

Data angket dari orangtua yang terkumpul pada akhirnya akan dijadikan dalam bentuk persentase dan dikategorikan dengan kategori sebagai berikut:

\section{$0-25 \%=$ Media Stekpan Sangat Tidak Layak \\ 26-50\%= Media Stekpan Tidak Layak \\ $51-75 \%=$ Media Stekpan Cukup Layak \\ 76-100\%- Media Stekpan Layak digunakan}

Berhubungan tampilan dengan video tutorial penggunaan media stekpan dapat dilihat pada gambar di bawah ini:

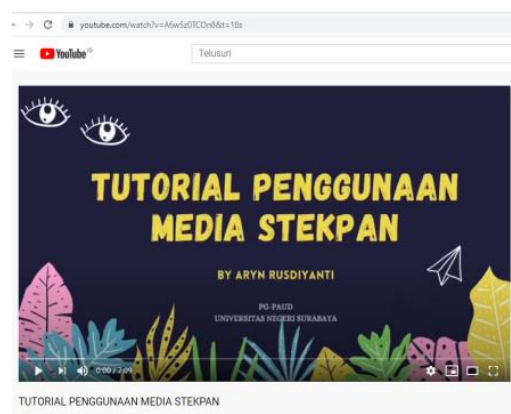

Gambar 14. Link Video Youtube Tutorial Penggunaan Media STEKPAN

https://www.youtube.com/watch?v=A6w5z0TCOn8\&t=1 $\underline{8 \mathrm{~s}}$

Di dalam video tutorial berisikan mengenai perkenalan peneliti, memperkenalkan media stekpan dan spesifikasinya, dan cara menggunakan media STEKPAn secara urut serta contoh cara mengaplikasikan pada seorang anak.

Tampilan dari bentuk dan pertanyaan dalam google form dapat di lihat pada gambar 15 di bawah ini:

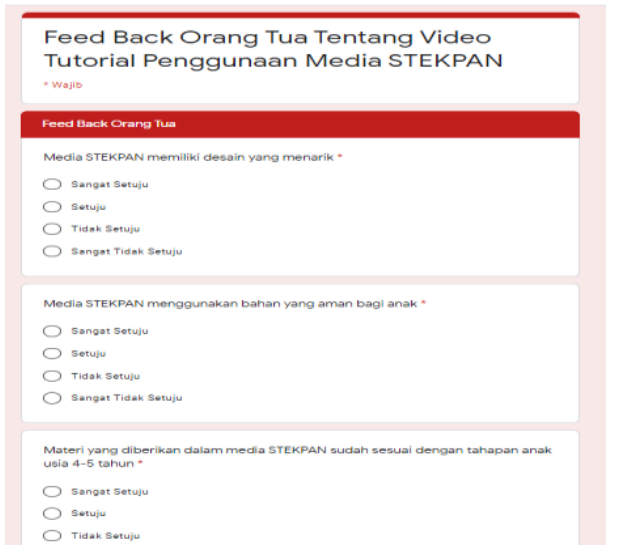


Gambar 15. Link Video Youtube Tutorial Penggunaan Media STEKPAN

https://forms.gle/gDCKSg1haRQyBE5A6

Adapun hasil akhir dari pengolahan data 50 responden ialah sebanyak $80 \%$ menyatakan bahwa media STEKPAN layak digunakan untuk membantu orang tua mengenalkan serta mengajarkan konsep bilangan 1-10 pada anak usia 4-5 tahun. sebesar $80 \%$. Adapun penjabaran hasil data yang didapat sebagai berikut:

Tabel 5. Hasil Uji Kelayakan atau Feed Back Orang Tua

\begin{tabular}{|c|c|}
\hline Persentase & Jumlah Responden \\
\hline $74 \%$ & 1 orang \\
\hline $75 \%$ & 1 orang \\
\hline $76 \%$ & 2 orang \\
\hline $77 \%$ & 9 orang \\
\hline $78 \%$ & 3 orang \\
\hline $79 \%$ & 6 orang \\
\hline $80 \%$ & 7 orang \\
\hline $81 \%$ & 10 orang \\
\hline $83 \%$ & 4 orang \\
\hline $84 \%$ & 3 orang \\
\hline $85 \%$ & 4 orang \\
\hline
\end{tabular}

Pada Tabel 4 terlihat persentase tertinggi sebanyak $85 \%$ dengan jumlah 4 orang responden. Persentase terendah terdapat pada $74 \%$ dan $75 \%$ yang masing-masing berjumlah 1 orang responden. Jumlah responden terbanyak ada pada persentase $81 \%$ yaitu sebanyak 10 orang responden. Dapat digambarkan lebih jelas menggunakan diagram seperti berikut:

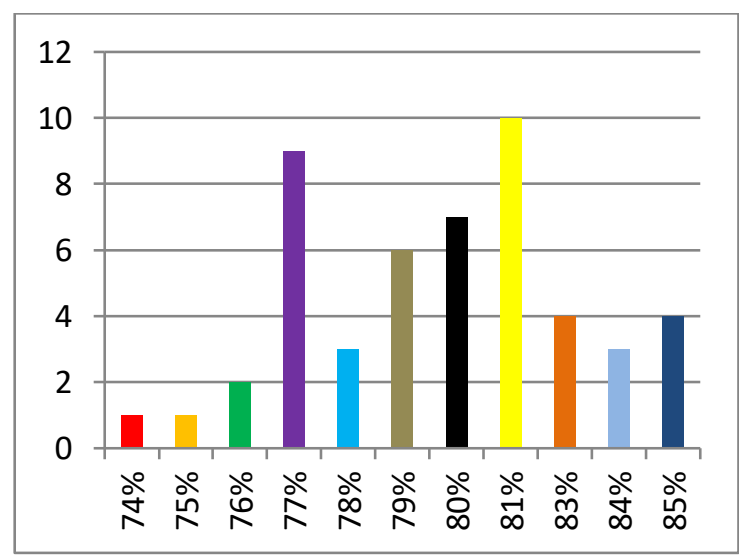

Gambar 16. Diagram Persentase Hasil Data Kelayakan Media STEKPAN Orang Tua

Tabel 6. Nilai Rata-Rata Hasil Responden

\begin{tabular}{|c|c|c|}
\hline $\begin{array}{c}\text { Presentase } \\
(\%)\end{array}$ & $\begin{array}{c}\text { Responden } \\
\text { (orang) }\end{array}$ & $\begin{array}{c}\text { Jumlah } \\
(\%)\end{array}$ \\
\hline 74 & 1 & 74 \\
\hline 75 & 1 & 75 \\
\hline 76 & 2 & 152 \\
\hline 77 & 9 & 693 \\
\hline 78 & 3 & 234 \\
\hline 79 & 6 & 474 \\
\hline 80 & 7 & 560 \\
\hline 81 & 10 & 810 \\
\hline 83 & 4 & 332 \\
\hline 84 & 3 & 252 \\
\hline 85 & 4 & 340 \\
\hline & \multicolumn{2}{|c|}{$\begin{array}{c}\sum \text { gabungan }=\frac{3996}{50} \times 100 \% \\
=80 \%\end{array}$} \\
\hline
\end{tabular}

Pada tabel di atas, dari hasil data 50 responden memenunjukkan bahwa produk media STEKPAN memiliki kefektifan dan kelayakan untuk digunakan sebanyak $80 \%$. Kategori pendapat orang tua sebesar $80 \%$ ini masuk dalam kategori layak. Hasil penelitian ini sesuai dengan hasil penelitian dari Lestari \& Prima (2019) yang mengungkapkan bahwa melalui permainan congklak kemampuan mengenali konsep bilangan lebih meningkat dibandingkan anak yang tidak ikut bermain. Hal ini menandakan bahwa adanya alat bantu akan sangat mendorong anak lebih memiliki kemampuan berpikir simbolik khususnya pada kemampuan mengenal lambang bilangan dan penggunaannya lebih optimal.

\section{SIMPULAN DAN SARAN}

Berdasarkan hasil pada pembahasan maka penelitian ini dapat disimpulkan bahwa media pembelajaran STEKPAN sangat efektif dalam membantu orang tua untuk mengenalkan konsep bilangan 1-10 pada anak dengan cara yang lebih menyenangkan karena dilakukan dengan bermain, terlebih lagi mengingat kondisi saat ini yang mana anak-anak harus melakukan kegiatan pembelajaran di rumah masing-masing. Media STEKPAN dikatakan layak untuk diproduksi sesuai dengan hasil data dari 50 orang tua sebagai responden dengan presentase rata-rata sebanyak $80 \%$.

Media STEKPAN memiliki tahapan yang sudah sesuai dengan apa yang harus dilalui oleh anak usia 4-5 tahun sehingga menjamin bahwa media 
STEKPAN sangat tepat digunakan oleh anak dengan materi yang sudah tepat.

Penelitian ini memiliki keterbatasan sebagaimana penelitian dilakukan dengan menggunakan feed back orang tua secara online. Hal ini dilakukan karena adanya COVID-19 yang menghambat gerak peneliti.

Berdasarkan simpulan hasil penelitian penulis memberikan saran kepada para orang tua anak usia 4-5 tahun untuk meningkatkan kegiatan belajar sembari bermain pada anak ketika dirumah. Melalui penggunaan alat dan kegiatan yang tepat orang tua akan lebih mudah mengajak dan mengajarkan suatu pembelajaran ke anak.

Peneliti melakukan penelitian hanya sampai pada tahap pengembangan berupa video tutorial penggunaan media STEKPAN yang berfungsi untuk mengetahui apakah produk sudah layak atau tidak untuk anak usia 4-5 tahun ditinjau dari sudut pandang orangtua. Jika sudah layak dapat digunakan sebagai acuan awal sebelum membuat produk yang dapat diproduksi serta diuji cobakan di lapangan nanti oleh peneliti selanjutnya.

Penelitian yang dilakukan peneliti selanjutnya disarankan dapat melakukan uji coba lapangan kepada anak serta mengobservasi perkembangan kognitif anak di sekolah. Penelitian eksperimen bersifat longitudinal sangat disarankan, untuk pengembangan media pembelajaran STEKPAN diharapkan untuk peneliti selanjutnya dapat menciptakan media STEKPAN lebih bervariasi dan dapat dikembangkan untuk anak usia 5-6 tahun.

Kendala yang peneliti alami yaitu tidak bisa secara langsung menerapkan di sekolah karena adanya konsdisi dan situasi yang tidak memungkinkan dikarenakan adanya virus COVID 19 yang mengakibatkan pemebelajaran disekolah dialihkan menjadi pembelajaran di rumah saja.

\section{DAFTAR PUSTAKA}

Akdon \& Riduwan. (2013). Rumus dan Data dalam Analisis Statistika. Bandung: Alfabeta.

Azhari, R. (2018). Pengembangan Media Komik Pengenalan Karir Siswa Kelas 4-5. Skripsi. Bimbingan Konseling. Fakultas Ilmu Pendidikan. Universitas Negeri Surabaya: Surabaya

Fauziddin. (2015). Peningkatan Kemampuan Matematika Anak Usia Dini Melalui Permainan
Jam Pintar di Taman Kanak - Kanak Pembina Kec. Bangkinang Kota. Jurnal PAUD Tambusai. Vol. 1, No. 1.

Fedriyenti. (2012). Peningkatan Kemampuan Matematika Anak Usia Dini Melalui Permainan Jam Pintar Di Taman Kanak - Kanak Pembina Kec. Barangin Sawahlunto. Jurnal Paud. Universitas Negeri Padang.

Jannah, R. (2011). Membuat Anak Cinta Matematika dan Eksak Lainnya. Jogjakarta: Iva Press.

Lillard, A.S. (2013). Playful Learning and Montessori Education. Journal. American: American Journal of Play

Lestari, P.I. \& Prima, E. (2019). Balinese Congklak Games, Maciwa, to Improve the Development of Symbolic Thinking in Early Childhood. Jurnal Obsesi, Vol 3. No.1.

Nurhayati \& Kharizmi, M. (2020). Penggunaan Media Stik Es Krim Untuk Meningkatkan Kemampuan Mengenal Konsep Bilangan Pada Anak Usia Dini Di Tks Tiga Serangkai Geulumpang Sulu Timur. .Jupegu-Aud : Jurnal Pendidikan Guru Anak Usia Dini. Vol.01, No.01

Nursalim, M. P. (2019). Mitos Di Media Sosial Terkait Pilpres 2019. PIKTORIAL: Journal of Humanities, 1(1), 1-14.

Parwati, dkk. (2013). Penerapan Pembelajaran Picture And Picture Berbantuan Media Kartu Angka Bergambar Dapat Meningkatkan Perkembangan Kognitif. Jurnal PAUD Undiksha.

Putra, Y.R. (2018). Pengembangan Aplikasi SmallSided Games Under 12 Berbasis Android. Skripsi. Universitas Negeri Yogyakarta.

Rasyid, I., \& Rohani. (2018). Manfaat Media dalam Pembelajaran. Jurnal Axiom. Vol. 7, No. 1

Sofnidar \& Yuliana. (2018). Pengembangan Media Melalui Aplikasi Adobe Flash dan Photoshop Berbasis Pendekatan Saintifik. Jurnal Gentala Pendidikan Dasar. Vol. 3, No. 2

Sugiyono. (2014). Metode Penelitian Kuantitatif, Kualitatif, dan R\&D. Bandung: Alfabeta.

Suhariyanik. (2015). Mengembangkan Kemampuan Berhitung Dalam Mengenal Bilangan 1-10 Menggunakan Media Stik Eskrim Warna Pada Anak Kelompok A Tk Kusuma Mulia Ii Kecamatan Tarokan Kabupaten Kediri Tahun Pelajaran 2015/2016. Jurnal PAUD. Universitas Nusantara PGRI.

Sulistyo, W.D., \& Wiradimadja, A. (2019). Lesson Study (LS): Memahamkan "Masalah Penelitian" kepada mahasiswa. Jurnal Teori dan Praktis Pembelajaran IPS, 29-37. Jakarta.

Supardi. (2019). Arah Pendidikan di Indonesia 
dalam Tataran Kebijakan dan Implementasi. Universitas Indraprasta PGRI.

Susani, N.K.K.P., dkk. (2017). Pengaruh Model Pembelajaran Teams Games Tournament Melalui Permainan Congklak Terhadap Perkembangan Berpikir Simbolik Anak.

Trisnawaty, I. K. A. P. \& I. G. A. O. N. (2017). Bilangan Pada Anak Kelompok B Fakultas Ilmu Pendidikan Universitas Pendidikan Ganesha. $e$ Journal Pendidikan Anak Usia Dini. Vol. 5, No. 1.

Undang-Undang Republik Indonesia Nomor 20 tahun 2003 tentang Sistem Pendidikan Nasional (Sisdiknas)

Umayah \& Khotimah, N. (2015). Peningkatan Kemampuan Kognitif Anak Melalui Permainan Congklak Pada Kelompok A. Jurnal PAUD. Universitas Negeri Surabaya.

Wahyudin., \& Agustin, M. (2011). Penilaian Perkembangan Anak Usia Dini. Bandung: Refika Aditama.

Yeni, E. M. (2015). Kesulitan Belajar Matematika Di Sekolah Dasar Jupendas. Vol. 2, No. 2. 